\title{
ROLUL EREDITĂȚII ȘI AL EDUCAȚIEI ÎN APARIȚIA ȘI DEZVOLTAREA COMPORTAMENTULUI HOMOSEXUAL
}

Ilie Cristian MANTA*

\begin{abstract}
The Role of Heredity and Education in the Emergence and Development of Homosexual Behavior ${ }^{\text {. }}$. It is currently recognized that biological data and external factors, genes, and the environment interact strongly, mutually influence each other, and some human traits can no longer be explained by supporting only biology or experience alone, but the answer can be found by studying the interaction between biology and the environment. This study presents the main scientific theories about the influence that genes and environmental factors exert on human development in general and on (homo) sexual behavior in particular, as well as how the Christian education based on the teaching of our Lord Jesus Christ contributes to the development of a healthy human behavior.
\end{abstract}

Keywords: nature, nurture, interaction, human development, (homo) sexual behavior.

\section{Introducere}

Pentru o mai bună înțelegere a celor discutate, se impune de la început o lămurire asupra termenilor: orientare și atracție sexuală, comportament sexual, identitate sexuală și identitate de gen. Astfel ,atracția sexuală faţă de un individ de un anumit sex este considerată a fi componenta principală a orientării sexuale, iar comportamentul sexual manifestarea orientării sexuale în raport cu un obiect atrăgător, identitatea

\footnotetext{
*PhD Student, Faculty of Orthodox Theology "Sfântul Andrei Şaguna" at "Lucian Blaga" University, Sibiu, Romania.

${ }^{1}$ Studiu redactat sub îndrumarea Prof. Univ. Dr. Sebastian Moldovan, care şi-a exprimat acordul pentru publicare.
} 
de sine ${ }^{2}$ este considerată de unii autori doar ca o autoevaluare personală a orientării sexuale: homo-, bi-, sau hetero-sexuală"’3.

Identitatea sexuală are în vedere mai ales dimensiunile biologice ale existenței noastre, echipamentul biologic cu care fiecare din noi am fost înzestrați, în timp ce identitatea de gen se referă în special la comportamentele, la rolurile pe care o persoană le asumă la nivel social, cum ar fi rolul de bărbat și femeie sau cel de mamă și tată. Dacă atracția, orientarea şi comportamentul sexual au în vedere relațiile intime, identitatea de gen se referă la manifestarea noastră socială, care poate angaja sau nu propria sexualitate. În cazul monahilor, spre exemplu, putem vorbi de o identitate sexuală bine definită prin trăsături sexuale, genetice, hormonale, fiziologice, neurologice, psihologice și de relație dar care, la nivel social, nu se manifestă deplin, de exemplu prin segregarea comunităţilor de monahi de cele de monahii. Pentru că au asumat votul castității, ei nu vor fi, de regulă părinți trupești, însă își asumă rolul de părinți duhovnicești.

\section{Factorii determinanți ai atracției și orientării sexuale}

În privința factorilor care determină orientarea sexuală, opiniile oamenilor de știință sunt diferite. O primă opinie amintită aici, este aceea că orientarea sexuală este puternic influențată genetic. Cel mai aprig susținător al determinării genetice a orientării homosexuale este psihologul american Michael Bailey, cunoscut pentru munca sa în domeniul etiologiei orientării sexuale.

Într-un studiu din 2014, Bailey a încercat să identifice dacă unii bărbaţi sunt predispuși să devină homosexuali, testând $\mathrm{ADN}$-ul prelevat de la peste 400 de seturi de fraţi homosexuali și de la rudele lor homosexuale. Concluzia acestui studiu era că „orientarea sexuală a unui bărbat este determinată în proporţie de $30-40 \%$ de factori genetici" ${ }^{4}$. Dr.

${ }^{2}$ Identitatea de sine are aici înțelesul de conștiință de sine.

3 Eugene V. DAEV, „Biological and Social Aspects of Human Sexual Orientation: Chemocommunicative Hypothesis", în Russian Journal of Genetics: Applied Research, Vol. 8, No. 1, 2018, p. 4.

${ }^{4}$ Antonia Molloy, Male homosexuality influenced by genes, US study finds, disponibil la: https://www.independent.co.uk/news/world/americas/male-homosexualityinfluenced-by-genes-us-study-finds-9127683.html (accesat la 23.05.2019), apud 
Bailey a declarat: „Orientarea sexuală nu are nimic de-a face cu alegerea. Constatările noastre sugerează că pot să fie gene în joc - noi am găsit dovezi despre două seturi [de gene] care influenţează dacă un bărbat este gay sau heterosexual "5. Dr. Bailey recunoaște implicarea factorilor de mediu în determinarea orientării sexuale, susținând că nu depinde totul de gene, însă lansează îndemnul de a nu confunda factorii de mediu cu «achizițiile sociale». „(Factor de) mediu înseamnă orice nu se află în ADN-ul nostru la naștere, iar asta include foarte multe lucruri care nu sunt sociale",

Într-un studiu mai vechi (1991) realizat de Bailey împreună cu Pillard, au fost examinate 56 de perechi de gemeni 'univitelini' şi 54 de perechi de gemeni 'bivitelini', 142 de fraţi ai gemenilor şi 57 de perechi de fraţi adoptivi. Ipoteza lor era aceea că dacă homosexualitatea este o trăsătură moştenită, atunci este de aşteptat ca mai mulţi fraţi gemeni să aibă aceeaşi orientare sexuală decât fraţii nonbiologici sau cei care nu sunt gemeni. Rezultatele studiului au arătat că $52 \%$ dintre gemenii univitelini, $22 \%$ dintre gemenii bivitelini și 9,2\% dintre fraţii adoptivi erau şi ei homosexuali ${ }^{7}$.

Rezultatele unui studiu mai amplu realizat în 2000, care a examinat cca. 5000 de gemeni adulți, au arătat faptul că 24\% dintre gemenii univitelini şi $15 \%$ dintre gemeni bivitelini erau şi ei homosexuali ${ }^{8}$. Indiferent dacă concordanța a fost de $24 \%$ sau $52 \%$ (primele studii), toate arată clar că nu poate fi vorba de un procent de $100 \%$, lucru ce ar fi de aşteptat în cazul gemenilor univitelini care, practic, au material genetic identic. Prin urmare, chiar dacă ar exista posibilitatea unei contribuții

Robert AnCuCEANu, Născut altfel? O explorare de peste 30 de ani a etiologiei homosexualității, disponibil la: https://semneletimpului.ro/social/gay/nascut-altfel-oexplorare-de-peste-30-de-ani-a-etiologiei-homosexualitatii-2.html (accesat la 23.05.2019).

5 Ibidem.

${ }^{6}$ Ibidem.

7 J. Michael BAIley, Richard C. Pillard, ,A genetic study of male sexual orientation ”, în Arch Gen Psychiatry, Vol. 48, No. 12, 1991, p. 1089-1096.

8 J. Michael Bailey, Michael P. Dunne, Nicholas G. Martin, „Genetic and environmental influences on sexual orientation and its correlates in an Australian twin sample", în Journal of Personality and Social Psychology, Vol. 78, No. 3, 2000, p. 524-536. 
genetice în determinarea atracției și orientării homosexuale, rolul genelor nu este unul covârşitor. Acest lucru este subliniat și de cel mai mare studiu despre rolul genelor în privința comportamentului homosexual, publicat în august $2019^{9}$, la care au participat 493.001 de persoane din Statele Unite, Regatul Unit și Suedia. Potrivit lui Andrea Ganna, autorul principal al studiului, genetician la Broad Institute of MIT și Harvard din Cambridge, Massachusetts, nu există o genă gay și chiar dacă preferințele sexuale au o componentă genetică, ,nici o genă nu are efect major asupra comportamentelor sexuale"10.

La fel precum și în cazul celorlalte comportamente umane, există o multitudine de efecte genetice ale genomului uman, fiecare având mica lor contribuţie în dezvoltarea persoanei. Studiul a identificat cinci loci genetici, (locus însemnând poziția unei gene pe cromozom), cinci puncte ale genomului uman care sunt legate de comportamentul homosexual, dar niciunul dintre markeri nu este suficient de fiabil pentru a prezice sexualitatea cuiva. Potrivit lui Ganna, comportamentul sexual poate fi explicat de genetică într-un procent de până la $25 \%$, restul reprezentândo influența mediului și a factorilor culturali ${ }^{11}$.

Dacă putem vorbi de o influență evidentă a factorilor genetici în apariția cancerului mamar și ovarian ${ }^{12}$, nu se poate spune acelaşi lucru în privința etiologiei homosexualității, cercetarea referitoare la contribuția genelor în dezvoltarea homosexualitații fiind în mare parte una nereușită, concluzia larg răspândită fiind aceea că o contribuție genetică semnificativă nu poate fi dovedită. Există voci numeroase, chiar în rândul activiștilor gay, ca de altfel și Journal of Homosexuality, care nu mai

${ }^{9}$ Andrea GANNA et alli, ,Large-scale GWAS reveals insights into the genetic architecture of same-sex sexual behavior", în Science, Vol. 365, No. 6456, 2019, disponibil la: https://geneticsexbehavior.info/wp-content/uploads/2019/08/ganna190830.pdf (accesat la 28.09.2019).

10 Jonathan LAMBERT, No 'gay gene': Massive study homes in on genetic basis of human sexuality, disponibil la: https://www.nature.com/articles/d41586-019-02585-6 (accesat la 25.09.2019).

${ }^{11}$ Ibidem.

12 Jeff M. HALL, et alli, „Linkage of early-onset familial breast cancer to chromosome 17q21", în Science, New Series, Vol. 250, No. 4988, (Dec. 2, 1990), p. 1684-1689. Este vorba de asocierea dintre cancerul mamar și prezența genei BRCA de pe cromozomul 17. 
susțin teoria „genei gay” sau cea a „creierului gay”, ci afirmă faptul că homosexualitatea este „o sărbătoare a autonomiei și libertății personale" ${ }^{\prime 13}$.

O altă opinie în comunitatea științifică susține că la naștere nounăscutul este în esență neutru din punct de vedere al atracției și orientării sexuale și că acestea se dezvoltă de-a lungul copilăriei, fiind influențate de o varietate de factori sociali. Există cercetări care indică faptul că orientarea sexuală poate fi, de exemplu, influențată de experiențele sexuale timpuri, de experiențele sexuale abuzive din copilărie și de consumul de pornografie. Spre exemplu, un studiu realizat de Van Wyk și Geist în 1984 arată că „,contactul homosexual la băieți influențează homosexualitatea adulților"14. Un alt element important din acest studiu, care foloseștele datele adunate de Kinsey de la 11000 de subiecți între anii 1938-1963, este acela că probabilitatea de a adopta homosexualitatea ca orientare la maturitate este mai mare cu cât o persoană află mai repede despre homosexualitate sau chiar trăiește o experiență homosexuală. Din studiul lui Wyk rezultă că vârsta medie în care femeile devenite lesbiene au aflat despre homosexualitate a fost de 13.9 ani, iar la băieți de 12.0 ani.

Experiențele sexuale abuzive din copilărie influențează și ele orientarea sexuală. Sunt studii care indică faptul că între 40 și $50 \%$ dintre persoanele atrase de acelaşi sex au fost în copilărie victimele unui viol sau abuz sexual ${ }^{15}$. Amintesc aici un studiu al lui Doll et al din anul 1992, potrivit căruia ,37\% dintre cei 1001 de bărbaţi homosexuali și bisexuali au raportat că au fost abuzați în copilărie, dintre care $94 \%$ de către bărbați mai în vârstă"16. Rezultatele lui Doll par să susțină concluziile cercetării

${ }^{13}$ Chris Kempling, Curricula orientării sexuale: implicații pentru pedagogi, disponibil la: https://provita.ro/2018/02/15/curricula-orientarii-sexuale-implicatii-pentrupedagogi/ (accesat la 20.02.2018).

${ }^{14}$ Paul H. VAN WyK, Chrisann S. GEIST, „Psychosocial development of heterosexual, bisexual, and homosexual behavior", în Archives of Sexual Behavior, Vol. 13, No. 6, December 1984, p. 505-544.

15 Dale O'LEARY, et alli, The same-sex attraction factsheet, disponibil la: http://www.familieslink.co.uk/download/sept07/same\%20sex\%20alleged $\% 20$ fact $\% 2$ 0sheet.pdf (accesat la 28.04.2018).

${ }^{16}$ Lynda S. DoLl et alli, ,Self-reported childhood and adolescent sexual abuse among adult homosexual and bisexual men", în Child Abuse \& Neglect, Vol. 16, No. 6, November-December 1992, p. 855-864. 
lui Van Wyk și Geist din anul 1984, conform căreia experiențele cu persoane de același sex din copilărie sunt corelate cu orientarea adultului. Un studiu despre sănătatea adolescenților, realizat în anul 2003 de către McCreary Center Society în Columbia Britanică, susține această afirmație. În cazul băieților, $21 \%$ dintre tinerii bisexuali și homosexuali chestionați ( $15 \%$ versus $6 \%$ ) au raportat că au fost abuzați sexual, faţă de $2 \%$ din tinerii heterosexuali. În cazul fetelor, $65 \%$ dintre adolescentele bisexuale și lesbiene chestionate (36\% versus $29 \%$ ) au raportat că au fost abuzate sexual, față de $11 \%$ din tinerele heterosexuale ${ }^{17}$.

$\mathrm{O}$ a treia opinie susține faptul că la definirea atracției și orientării sexuale joacă un anumit rol felul în care factorii biologici din perioada embrionară conlucrează cu experiențele postnatale timpurii și chiar până la adolescență. Este vorba despre interacțiunea factorilor biologici cu cei de mediu, aspect cunoscut sub numele de distincția nature-nurture, formulată pentru prima dată de Francisc Galton în anul $1874^{18}$. Potrivit lui Galton, această distincție separă sub două aspecte diferite, nenumărate elemente din care se compune personalitatea umană: ,nature se referă la tot ceea ce un om aduce cu el în lume, în timp ce nurture se referă la orice influență din afară care afectează omul după naștere"19. Altfel spus, nature se referă la toate genele și la factorii ereditari care influențează identitatea noastră - de la aspectul fizic la caracteristicile de personalitate, iar nurture la toate aspectele de mediu care influențează identitatea noastră, inclusiv experiențele timpurii din copilărie, cultura și modul în care am fost crescuți, relațiile sociale. Nature se referă la structurile și procesele biologice, iar nurture se referă la influențele socio-culturale.

În conturarea trăsăturilor umane și în formarea comportamentului uman sunt implicați atât factorii ereditari, biologici, cât și cei de mediu. Dacă în anumite aspecte referitoare la stabilirea trăsăturilor fizice, rolul determinant îl au factorii ereditari (culoarea pielii, a părului sau a ochilor),

${ }^{17}$ Elisabeth SAEWYC et alli, Not Yet Equal: The Health of Lesbian, Gay, \& Bisexual Youth in $B C$, disponibil la: https://www.mcs.bc.ca/pdf/not_yet_equal_web.pdf (accesat la 28.09.2019).

${ }^{18}$ Francisc Galton, English Men of Science: Their Nature and Nurture, London, Macmillan \& Co, 1874.

19 Christopher R. BADCOCK, Nature-Nurture Controversy, History Of, disponibil la: https://www.psychologytoday.com/sites/default/files/nature-nurture_controversy.pdf (accesat la 23.07.2018). 
în altele, rolul predominant revine factorilor de mediu. De exemplu, comportamentul agresiv poate fi învățat sesizând pur și simplu modul violent de manifestare al copiilor mai mari pe câmpul de joacă sau din filme, în timp ce modul politicos de comportare poate fi învățat de un copil direct de la părinți.

\section{Interacțiunea factorilor de mediu cu cei ereditari și rolul ei în dezvoltarea umană}

Galton afirmă că nature și nurture interacționează şi se influențează reciproc și susține că ,cele mai înalte înzestrări naturale pot fi afectate de elemente defectuoase ce țin de nurture (de dezvoltare), iar o dezvoltare sănătoasă poate surmonta tendințele rele ale unui organism intrinsec rău, ale unui creier slab sau ale unor dispoziții brutale"20.

Interacțiunea factorilor de mediu cu cei ereditari este foarte importantă în devenirea noastră. Anumiţi factori de mediu pot influența puternic modul de exprimare al genelor noastre sau, cu alte cuvinte, fenotipul nostru este afectat de diferitele noastre experiențe.

Într-un studiu realizat în anul 2003, Lickliter și Honeycutt susțin faptul că ,într-una din interacțiunile importante dintre nature și nurture, genele nu funcționează ca unități încapsulate ale eredității, ci ca sisteme de răspuns foarte dependente de mediul exterior"21. Cazul mamelor înfometate în timpul perioadei de sarcină, cum ar fi de pildă, foametea la care a fost expusă populația din Olanda în iarna anilor 1944-1945 22 sau studiile asupra copiilor supraviețuitorilor Holocaustului ${ }^{23}$ reprezintă exemple care atestă că influențele genetice depind de mediul social, expunerea la factori severi de stres producând schimbări evidente în genele relevante.

${ }^{20}$ Francis Galton, English Men of Science: Their Nature and Nurture, p. 12-13, apud Christopher R. BADCOCK, Nature-Nurture Controversy, History Of.

21 Robert LiCKLITER, Hunter HonEYCUTT, „Developmental dynamics: Toward a biologically plausible evolutionary psychology", în Psychological Bulletin, Vol. 129, No. 6, 2003, p. 819-835.

22 LH LUMEY, et alli, „Cohort profile: the Dutch hunger winter families study”, în International Journal of Epidemiology, Vol. 36, No. 6, December 2007, p. 1196-1204.

${ }^{23}$ Mallory E. Bowers, Rachel YeHUDA, „Intergenerational Transmission of Stress in Humans", în Neuropsychopharmacology, Vol. 41, No. 1, 2016, p. 232-244. 
Prin urmare, influențele genetice pot depinde de mediul social, exprimarea genelor într-un anume fel fiind rezultatul interacţiunii cu diverşi factori de mediu. Putem astfel afirma faptul că fiecare dintre noi suntem influențaţi de genele noastre, de ceea ce moștenim de la părinți, dar suntem influențați într-o oarecare măsură și de educația primită de la cei cu care relaționăm (părinți, școală, biserică, media etc). De exemplu, părinții ne influențează atât în biologia noastră, cât şi în felul nostru de a fi, în comportamentul nostru prin ,moştenire genetică regulată", adică prin zestrea ereditară pe care o primim de la ei, prin educația pe care ne-o transmit, dar și prin experiențele lor de viață, prin felul lor de a trăi viața ${ }^{24}$. În devenirea noastră putem fi influențaţi de asemenea de experiențele noastre proprii şi de experiențele altora. Am amintit mai sus date care indică faptul că între 40 și $50 \%$ dintre persoanele atrase de același sex au fost în copilărie victimele unui viol sau abuz sexual.

Suntem deci definiți într-o oarecare măsură de genele moștenite, însă ereditatea nu reprezintă factorul principal în devenirea noastră. Unii suntem influențaţi într-o măsură mai mare de ereditate, de biologia noastră, alții, de factorii de mediu precum: educaţia parentală, factori culturali, factori sociali, factori de stres etc. În prezent, anumite trăsături umane nu mai pot fi explicate sprijinindu-ne numai pe biologie sau numai pe experienţă. Apare astfel evident faptul că „datul biologic și factorii externi, genele și mediul, interacționează puternic"25, iar devenirea noastră este rezultatul acestei interacțiuni.

Potrivit cercetătorului belgian Jacques Balthazart, interacțiunea dintre „procesele biologice din timpul vieții embrionare și al celei postnatale timpurii" 26 are un rol major și în ceea ce privește determinarea orientării sexuale. Balthazart citează studiul lui Blanchard și Bogaert realizat în 1996, din care reiese faptul că în familiile în care se nasc mai mult băieți, probabilitatea ca unul dintre ei să devină homosexual crește cu aproximativ

\section{${ }^{24}$ Ibidem.}

25 Graham Music, Nurturing Natures. Attachment and Children's Emotional, Sociocultural and Brain Development, Second Edition, Routledge, 2017, p. 109.

${ }^{26}$ Jacques BALTHAZART, „Fraternal birth order effect on sexual orientation explained”, in PNAS, Vol. 115, No. 2, 2018, p. 234-236. 
$33 \%$ cu fiecare frate mai mare născut de aceeași mamă ${ }^{27}$. Este vorba de așa numitul efect al ordinii nașterii frățești - fraternal birth order effect (FBOE), cunoscut și sub denumirea de ipoteza imunizării materne - the maternal imunization hypothesis (MIH). Potrivit unui studiu mai recent realizat de Blanchard, procentul bărbaţilor homosexuali care recunosc că orientarea lor sexuală se datorează acestui efect este între $15-29 \%{ }^{28}$. Explicaţia FBOE constă în, ,imunizare progresivă a mamei care poartă embrioni masculi împotriva unui antigen masculin. Anticorpii se acumulează de-a lungul sarcinilor succesive și vor interfera din ce în ce mai mult cu dezvoltarea creierului embrionar al fiilor ulteriori" ${ }^{29}$. Cu alte cuvinte:

,....anumite substanțe prezente pe suprafața celulelor creierului masculin (e vorba aici de neurolignina 4, NLGN4Y), pătrund în corpul mamei. Sistemul imunitar al mamei recunoaște aceste substanțe ca fiind străine şi le produce anticorpi. Când mama devine mai târziu însărcinată cu un alt făt mascul, anticorpii ei traversează bariera placentară și intră în creierul fetal, modificând modelul tipic masculin al dezvoltării creierului și cauzând preferințe sexuale în dezacord cu constituția fizică" ${ }^{30}$.

Dacă, potrivit lui Blanchard, FOBE este ,de departe factorul cel mai larg răspândit care influențează orientarea sexuală la bărbați”’31, întrun studiu ${ }^{32}$ din 2018, fără a nega contribuția pe care FBOE o are în apariția homosexualității masculine, autorii lui consideră că FBOE nu poate constitui o explicație generală a homosexualității. Fără a putea prezenta

${ }^{27}$ Ray Blanchard, Anthony F. BOGAERT, „Homosexuality in men and number of older brothers", în Am J Psychiatry, Vol. 153, No. 1, 1996, p. 27-31.

${ }^{28}$ Idem, ,Quantitative and theoretical analyses of the relation between older brothers and homosexuality in men" în J Theor Biol, Vol. 230, No. 2, 2004, p. 173-187.

${ }^{29}$ Anthony F. BOGAERT, Malvina N. SKORSKA, ,Sexual orientation, fraternal birth order, and the maternal immune hypothesis: A review", în Front Neuroendocrinol, Vol. 32, No. 2, 2011, p. 247-254, apud Jacques BALTHAZART, „Fraternal birth order effect on sexual orientation explained",.

30 Serghey GAVRILETS, Urban FrIBERG, William R. RICE, „Understanding Homosexuality: Moving on from Patters to Mechanisms", în Archives of Sex Behavior, Vol. 47, No. 1, 2018, p. 27-31.

31 Ray BlANCHARD, „Fraternal birth order, family size, and male homosexuality: Metaanalysis of studies spanning 25 years", în Archives of Sexual Behavior, Vol. 47, No. 1, 2007, p. 1-15, apud Serghey Gavrilets, Urban FrIBERG, William R. RicE, „Understanding Homosexuality: Moving on from Patters to Mechanisms”.

32 Ibidem. 
pe larg argumentele lor, din lipsă de spațiu, precizez doar că autorii acestui studiu susțin că FBOE explică doar un procent relativ scăzut al homosexulității masculine; utilizând anumite date, arată faptul că FBOE poate fi invocat pentru a explica homosexualitatea unui bărbat din $7^{33}$ sau cel mult doi din $7^{34}$. Sunt și alte studii care nu sprijină $\mathrm{FBOE}^{35}$, neexistând până în prezent o explicație mecanică verificată a acestui fenomen.

\section{Educația parentală și comportamentul (homo)sexual}

Ideea unei determinări exclusiv genetice a homosexualității începe să piardă teren. În ceea ce privește sexualitatea, tot mai mulți cercetători susțin deschis faptul că ,trebuie să existe o componentă genetică a acesteia, dar nu poate să depindă totul de gene pentru că atunci, în cazul perechilor de gemeni identici, ambii ar fi fie homosexuali, fie heterosexuali. Ori realitatea ne arată că există gemenii identici, unul fiind homosexual, iar altul heterosexual. Trebuie să fie şi alţi factori care să joace un anumit rol"36.

Referindu-se la atitudinea membrilor Asociației Americane de Psihiatrie (APA), Dr. Dean Byrd, psihoterapeut, profesor și autor a peste 100 de articole și cărți despre sexualitatea umană, afirmă că mult timp aceștia ,au fost încredințaţi că homosexualitatea ar fi determinată biologic. În anul 2008, și-au schimbat poziția. Acum afirmă că e o combinație între factorii biologici și cei de mediu (între nature și nurture) şi că are cauze mult mai complexe decât ne-au spus în trecut"'37.

33 James M. Cantor, Ray Blanchard, Andrew D. Paterson, Anthony F. Bogaert, „How many gay men owe their sexual orientation to fraternal birth order?”, în Arch Sex Behav., Vol. 31, No. 1, 2002, p. 63-71, apud Serghey Gavrilets..., „Understanding Homosexuality: Moving on from Patters to Mechanisms”.

${ }^{34}$ Ray BlanChARD, Anthony F. BOGAERT, „Proportion of homosexual men who owe their sexual orientation to fraternal birth order: An estimate based on two national probability samples", în American Journal of Human Biology, Vol. 16, No. 2, 2004, p. 151-157, apud Serghey GAVRILETS..., „Understanding Homosexuality: Moving on from Patters to Mechanisms".

35 Simon LeVAy, Gay, straight, and the reason why: The science of sexual orientation (2nd ed.). Oxford, UK: Oxford University Press 2016, apud Serghey Gavrilets..., „Understanding Homosexuality: Moving on from Patters to Mechanisms”.

${ }^{36}$ National Geographic explains the biology of homosexuality, disponibil la: https://www. youtube.com/watch?v=saO_RFWWVVA (accesat la 17.05.2019).

37 Family Watch International, Understanding Same-Sex Attraction, disponibil la: https://www.youtube.com/watch?v=jJhyzqdzpnM (accesat la 5.07.2018). 
Astfel, ideea tot mai mult vehiculată este cea potrivit căreia homosexualitatea are cauze mult mai complexe, existând o varietate de factori care contribuie la dezvoltarea unei orientări homosexuale. Aceștia nu se manifestă la toți homosexualii, unii fiind influențaţi de anumiţi factori, alții de alți factori ${ }^{38}$.

Chiar dacă unii copii sunt mai influențabili decât alții, este evident faptul că, în formarea și dezvoltarea acestora, pe lângă contribuția genetică, un rol important îl joacă felul de educație primit, precum și tipul influenţelor de care un copil are parte ${ }^{39}$. Factori precum mediul familial, experiențele timpurii și educația pot influența comportamentul sexual al copilului și chiar al persoanei adulte. Amintesc în acest sens studiul realizat în 2018 de Lisa Littman ${ }^{40}$, care a chestionat 256 de părinți ai căror copii cu vârsta între 11-21 ani şi-au exprimat dorinţa să îşi schimbe sexul anatomic. Pe lângă faptul că mare parte din copiii părinților chestionați sufereau de maladii psihice, de stres, ori aveau probleme de tip emoțional, fiind traumatizați într-un anume fel, „85,9\% din părinții ai căror adolescenți se confruntau cu probleme de confuzie sexuală erau suporteri ai căsătoriilor între persoane de acelaşi sex și ai drepturilor persoanelor transgender. Dintre aceştia, majoritatea covârşitoare erau lesbiene, care ori că trăiau cu alte femei, ori în tinerețe s-au identificat ca fiind lesbiene" 41 . Studiul arată de asemenea faptul că:

${ }^{38}$ Ibidem.

39 Graham Music, Nurturing Natures. Attachment and Children's Emotional, Sociocultural and Brain Development, p. 278.

${ }^{40}$ Studiul având titlul: Rapid-onset gender dysphoria in adolescents and young adults: A study of parental reports a fost publicat inițial pe data de 16 august 2018, însă a fost retras de către Universitate pe data de 27 august, în urma unei campanii vicioase a grupurilor homosexuale și transgenderiste din America împotriva autoarei. El a fost republicat sub formă revizuită pe data de 19 martie 2019, având titlul: Parent reports of adolescents and young adults perceived to show signs of a rapid onset of gender dysphoria, disponibil la: https://journals.plos.org/plosone/article?id=10.1371/ journal.pone.0202330 (accesat la 19.05.2019).

${ }^{41}$ Lisa LiTTMAn, Rapid-onset gender dysphoria in adolescents and young adults: A study of parental reports, disponibil la: https://www.researchgate.net/publication/ 327065646_Rapid-onset_gender_dysphoria_in_adolescents_and_young_adults_A _study_of_paren tal_reports (accesat la 8.09.2018), apud Alianța Familiilor din România, Vagabonzii internetului și adevărul despre transgenderism, disponibil la: 
,21,5\% dintre părinții chestionaţi au dezvăluit că înainte ca proprii copii să se identifice ca fiind transgender, aceștia aveau prieteni ori cunoștințe apropiate care deja se identificau ca fiind transgender ori și-au schimbat sexul anatomic; $19,9 \%$ dintre părinţi au observat că în preajma perioadei când copiii s-au identificat ca fiind transgender, copii urmăreau online îndeaproape și cu multă curiozitate materiale și informații despre transgenderism şi persoane care şi-au schimbat sexul anatomic. Concluzia logică a lui Littman a fost că mediul din familie şi asocierea copiilor cu persoane care deja și-au schimbat sexul erau cauzele principale care i-au determinat să îmbrățișeze o identitate sexuală transgender. Acești copii și adolescenți sunt influențați să gândească, că singura cale pentru a confrunta problemele psihice cu care se confruntă, eliminarea stresului, şi, cel mai important, dobândirea fericirii, e prin schimbarea sexului anatomic" ${ }^{\prime 2}$.

Mediul timpuriu în care este crescut copilul își pune amprenta pe dezvoltarea lui de mai târziu. De exemplu, în situaţia în care un copil își pierde tatăl binevoitor și se ,alege” cu unul violent, copilul se adaptează la noul context ${ }^{43} . \mathrm{Cu}$ alte cuvinte, dacă părintele devine mai mult sau mai puțin sensibil, stilul de atașament al copilului se schimbă. Se pare că un ataşament securitar timpuriu poate reprezenta un tampon pentru loviturile socio-emoționale de mai târziu. Un copil de cincisprezece luni, liniștit și fără griji, ar putea avea doar un mic avans față de unul lipsit de apărare, însă este foarte posibil ca acești copii să rămână puternici și încrezători în următorii doi, patru sau zece ani, iar aceasta pentru că au rămas în sânul unei familii unde au avut parte de o gândire și creștere părintească sensibilă ${ }^{44}$.

Raportarea membrilor familiei la copil are impact major în ceea ce privește comportamentul sexual. O mamă dominantă, absența tatălui și lipsa lui de implicare în viața copilului pot determina o masculinizare

https://www.resursecrestine.ro/eseuri/180223/vagabonzii-internetului-si-adevaruldespre-transgenderism (accesat la 8.09.2018).

42 Ibidem.

43 Jay Belsky, Richard M. Pasco FeAron, „Early attachment security, subsequent maternal sensitivity, and later child development: does continuity in development depend upon continuity of caregiving?", în Attach Hum Dev., Vol. 4, No. 3, 2002, p. $361-387$.

44 Graham Music, Nurturing Natures. Attachment and Children's Emotional, Sociocultural and Brain Development, p. 268-269. 
rănită a acestuia. Iată ce spune în acest sens dr. Julie Herron Hamilton, fostă președintă a Asociației Naționale pentru Studiul şi Terapia Homosexualității:

„Percepțiile sunt totul. Ele nu reprezintă neapărat ce ni se întâmplă, ci felul în care percepem ceea ce ni se întâmplă. Așadar, dacă un băiat nu percepe mesajul că tatăl lui dorește să fie în relație cu el și nu îl întâmpină oferindu-i siguranța emoțională, atunci băiatul nu se va putea conecta cu el. De obicei, temperamentul unui copil care ajunge să fie atras de persoane de același sex este extrem de sensibil. Pune la inimă tot ce i se întâmplă, ia totul personal, chiar dacă nu aceasta a fost intenția"45.

George Rekers, un expert recunoscut în tulburarea identității de gen, autor și coautor a peste 60 de studii pe această temă, scrie: „Impactul privării paterne asupra dezvoltării psiho-sexuale este cel mai evident în studiile clinice retrospective ale bărbaților homosexuali și transsexuali”" ${ }^{\prime 6}$.

De asemenea, o mamă care vrea să fie mereu în control, ,sufocantă pentru băiat" și care își domină și soțul lăsând copilului impresia că bărbații ar fi slabi, îl poate priva pe acesta de o relație vie cu propriul tată. „Dacă fiul rămâne însetat de relația și atașamentul pe care nu le obține de la el (de la tată), sentimentul acela nu are cum să dispară, ci continuă să existe" ${ }^{47}$.

\section{Homosexualitatea și convingerile religioase}

Pe de o parte, din cele prezentate mai sus am putut observa faptul că anumite experiențe din copilăria timpurie pot afecta negativ dezvoltarea copiilor și mă refer mai ales la experiențele sexuale abuzive de care unii copii au avut parte. Pe de alte parte, un lucru îmbucurător este faptul că, de-a lungul timpului, copiii își pot construi noi experiențe prin intermediul învătării, pot dezvolta noi așteptări și noi modele interne de

45 Family Watch International, Understanding Same-Sex Attraction, disponibil la: https://www.youtube.com/watch?v=jJhyzqdzpnM (accesat la 5.07.2018).

46 George A. REKERS, „Gender identity disorder”, în The Journal of Human Sexuality, 1996, p. 11-20, apud Chris KEMPLING, Curricula orientării sexuale: implicții pentru pedagogi, disponibil la: https://provita.ro/2018/02/15/curricula-orientarii-sexualeimplicatii-pentru-pedagogi/ (accesat la 20.02.2018).

47 Family Watch InTERnational, Understanding Same-Sex Attraction, disponibil la: https:// www.youtube.com/watch?v=jJhyzqdzpnM (accesat la 5.07.2018). 
relaționare, prin care pot depăși anumite inconveniențe de care au avut parte. Este și cazul foștilor homosexuali care, la un anume moment al vieții, ajung să își reconsidere preferința sexuală.

Atunci când Hristos este pus în centru cunoașterii, El Care este Calea spre adevărata cunoaștere și Adevărul Însuși, transformarea în bine a omului este cu adevărat posibilă. De exemplu, participanții la Freedom March (Marșul Libertăţii) ${ }^{48}$, la care participă persoane foste LGBT, sunt o mărturie vie că, prin puterea Duhului Sfânt, eliberarea de păcatele sexuale și de rănile de tot felul este cu adevărat posibilă. Luis Javier Ruiz, unul dintre participanții la marșul de anul trecut, a afirmat că „transformarea aceasta nu se referă la trecerea de la situaţia de persoană gay la situația de persoană hetero, ci de la situația de persoană pierdută la situația de persoană mântuită, exprimând prin aceasta că transformarea calitativă este mult mai mare" 49 .

Într-un studiu din anul 1984, Kinsey raportează că relaţiile homosexuale sunt mai puțin răspândite printre oamenii care aparțin unor grupuri religioase ${ }^{50}$. Acest aspect nu este greu de înțeles, deoarece în familiile în care se pune un puternic accent pe valorile tradiționale, homosexualitatea este mai puțin acceptată decât în cazul famililor mai puțin ataşate de valorile tradiționale ${ }^{51}$. Persoanele din familii religioase

${ }^{48}$ Marșul Libertății care anul acesta a avut loc în Washington D.C. pe data de 25 mai 2019 este al doilea de acest fel. Primul s-a ținut în toamnă, în Los Angeles, alte două fiind programate a se desfășura în St. Paul (Minnesota), pe 23 iunie, respectiv Orlando, pentru data de 14 septembrie.

${ }^{49}$ Brandon SHOwALTER, Ex-LGBT men, women to share stories of transformation at 2 nd Freedom March in Washington, DC, disponibil la: https://www.christianpost.com/ news/ex-lgbt-men-women-to-share-stories-of-transformation-at-2nd-freedom-marchin-washington-dc.html (accesat la 25.05.2019), apud Ion Ciungu, Iisus în centrul cunoașterii....., disponibil la: https://doisautreiinnumeleluiiisus.blogspot.com/2019/05/iisus-in-centrul-cunoasteriiii-poate.html (accesat la 25.05.2019).

${ }^{50}$ Alfred KINSEY, et alli (1984), Sexual Behavior in the Human Male, Saunders, 1984, p. 483, apud FAMILy ReSEARCH InSTITUTE, What Causes Homosexual Desire and Can It Be Changed?, disponibil la: http://www.familyresearchinst.org/2009/02/what-causeshomos exual-desire-and-can-it-be-changed/\#fnref-222-1 (accesat la 27.09.2019).

${ }^{51}$ Bernie S. Newman, Peter G. Muzzonigro, , The effects of traditional family values on the coming out process of gay male adolescents", în Adolescence, Vol. 28, No. 109, 1993, p. 213-226. 
sunt crescute cu convingerea că homosexualitatea este imorală şi de neacceptat, ori de aici rezultă și riscul mai scăzut de implicare în activități homosexuale . $^{52}$.

\section{Concluzia}

În concluzie, cercetările științifice efectuate până în prezent afirmă că devenirea noastră este rezultatul interacțiunii diverșilor factori de mediu cu cei ereditari și fără a fi identificată până în prezent o contribuție genetică semnificativă în apariţia homosexualităţii, aceasta are cauze complexe, existând o varietate de factori precum experiențele sexuale timpurii, experiențele sexuale abuzive, un mediu parental mai puțin prielnic, care pot contribui la dezvoltarea atracției și orientării homosexuale, respectiv a unui comportament homosexual. De asemnea, educația are un rol extrem de important și, în funcție de felul în care este făcută, contribuie și ea la cristalizarea identității noastre sexuale.

Semnificația morală și pastorală a datelor științifice prezentate în acest articol face obiectul cercetării în desfășurare în cadrul tezei de doctorat intitulată „Semnificația morală a etiologiei comportamentului homosexual". Pe lângă diverși factori biologici sau de mediu care pot fi invocați în apariția homosexualității, aceasta are în primul rând cauze de natură spirituală. $O$ viață trăită fără a ține cont de logoi divini, de raționalitatea creației divine, îl lasă pe om fără apărare în fața asaltului patimilor. În schimb, o educație centrată pe învățătura Domnului Iisus Hristos, pe iubirea Lui nemărginită faţă de om, reprezintă, pe de o parte, un sprijin veritabil care să împiedice căderea în patima homosexualității, iar, pe de altă parte, în cazul în care aceasta a avut loc datorită nechibzuinței și nepurtării de grijă a omului, o certitudine că ridicarea și vindecarea sunt posibile.

\section{Referinţe bibliografice:}

1. ANCUCEANU, Robert, Născut altfel? O explorare de peste 30 de ani a etiologiei homosexualităţii, disponibil la: https://semneletimpului.

52 Family Research Institute, What Causes Homosexual Desire and Can It Be Changed?, disponibil la: http://www.familyresearchinst.org/2009/02/what-causeshomosexual-desire-and-can-it-be-changed/\#fnref-222-1 (accesat la 27.09.2019). 
ro/social/gay/nascut-altfel-o-explorare-de-peste-30-de-ani-a-etiologieihomosexualitatii-2.html (accesat la 23.05.2019);

2. BADCOCK, Christopher R. Nature-Nurture Controversy, History Of, disponibil

la: https://www.psychologytoday.com/sites/default/files/naturenurture_controversy.pdf (accesat la 23.07.2018);

3. Bailey, J. Michael, DunNe, Michael P., Martin, Nicholas G., „Genetic and environmental influences on sexual orientation and its correlates in an Australian twin sample", în Journal of Personality and Social Psychology, Vol. 78, No. 3, 2000, p. 524-536;

4. BAILEY, J. Michael, PILlaRD, Richard C., „A genetic study of male sexual orientation”, în Arch Gen Psychiatry, Vol. 48, No. 12, 1991, p. 1089-1096;

5. BALTHAZART, Jacques, „Fraternal birth order effect on sexual orientation explained", în PNAS, Vol. 115, No. 2, 2018, p. 234-236;

6. BELSKY, Jan, FEARON, Richard M. Pasco, „Early attachment security, subsequent maternal sensitivity, and later child development: does continuity in development depend upon continuity of caregiving?", în Attach Hum Dev., Vol. 4, No. 3, 2002, p. 361-387;

7. Blanchard, Ray, Bogaert, Anthony F., „Homosexuality in men and number of older brothers", în Am J Psychiatry, Vol. 153, No. 1, 1996, p. 27-31;

8. BOWERS, Mallory E., YEHUDA, Rachel, „Intergenerational Transmission of Stress in Humans", în Neuropsychopharmacology, Vol. 41, No. 1, 2016, p. 232-244;

9. CIungu, Ion, Iisus în centrul cunoașterii..., disponibil la: https://doisautreiinnumeleluiiisus.blogspot.com/2019/05/iisus-incentrul-cunoasterii-ii-poate.html (accesat la 25.05.2019);

10. DAEV, Eugene V., „Biological and Social Aspects of Human Sexual Orientation: Chemocommunicative Hypothesis”, în Russian Journal of Genetics: Applied Research, Vol. 8, No. 1, 2018, p. 1-10;

11. DoLL, Lynda S., et alli, „Self-reported childhood and adolescent sexual abuse among adult homosexual and bisexual men", în Child Abuse \& Neglect, Vol. 16, No. 6, November-December 1992, p. 855-864;

12. FAMILY Research InStitute, What Causes Homosexual Desire and Can It Be Changed?, disponibil la: http://www.familyresearchinst.org/ 2009/02/what-causes-homosexual-desire-and-can-it-be-changed/\#fnref222-1 (accesat la 27.09.2019); 
13. FAMILY WATCh INTERNATIONAL, Understanding Same-Sex Attraction, disponibil la: https://www.youtube.com/watch? $\mathrm{v}=\mathrm{j}$ JhyzqdzpnM (accesat la 5.07.2018);

14. Galton, Francisc, English Men of Science: Their Nature and Nurture, London, MACMILLAN \& CO, 1874;

15. GANNA, Andrea et alli, Large-scale GWAS reveals insights into the genetic architecture of same-sex sexual behavior, Science, 2019, Vol. 365, No. 6456, disponibil la: https://geneticsexbehavior.info/wpcontent/uploads/2019/08/ganna190830.pdf (accesat la 28.09.2019);

16. GAVRILETS, Serghey, FRIBERG, Urban, RICE, William R., „Understanding Homosexuality: Moving on from Patters to Mechanisms", in Archives of Sex Behavior, Vol. 47, No.1, 2018, p. 27-31;

17. HALL, Jeff M. et alli, „Linkage of early-onset familial breast cancer to chromosome 17q21", în Science, New Series, Vol. 250, No. 4988, (Dec. 2, 1990), p. 1684-1689;

18. http://www.familieslink.co.uk/download/sept07/same\%20sex\%20allege d\%20fact\%20sheet.pdf (accesat la 28.04.2018);

19. KemPling, Chris, Curricula orientării sexuale: implicții pentru pedagogi, disponibil la: https://provita.ro/2018/02/15/curriculaorientarii-sexuale-implicatii-pentru-pedagogi/ (accesat la 20.02.2018);

20. LAMBERT, Jonathan, No 'gay gene': Massive study homes in on genetic basis of human sexuality, disponibil la: https://www.nature. com/articles/d41586-019-02585-6 (accesat la 25.09.2019);

21. LICKLITER, Robert, HoNEYCUTT, Hunter, „Developmental dynamics: Toward a biologically plausible evolutionary psychology", în Psychological Bulletin, Vol. 129, No. 6, 2003, p. 819-835;

22. LitTMAN, Lisa, Rapid-onset gender dysphoria in adolescents and young adults: A study of parental reports, disponibil la: https://www. researchgate.net/publication/327065646_Rapid-onset_gender_dysphoria _in_adolescents_and_young_adults_A_study_of_parental_reports (accesat la 8.09.2018);

23. LUMEY, LH, et alli, „Cohort profile: the Dutch hunger winter families study", în International Journal of Epidemiology, Vol. 36, No. 6, December 2007, p. 1196-1204;

24. MusIC, Graham, Nurturing Natures. Attachment and Children's Emotional, Sociocultural and Brain Development, Second Edition, New York, Routledge, Taylor \& Francis Group, 2007; 
25. National Geographic explains the biology of homosexuality, disponibil la: https://www.youtube.com/watch? $\mathrm{v}=\mathrm{saO} \_$RFWWVVA (accesat la 17.05.2019);

26. Newman, Bernie S., Muzzonigro, Peter G., „,The effects of traditional family values on the coming out process of gay male adolescents", în Adolescence, Vol. 28, No. 109, 1993, p. 213-226;

27. O'LEARY, Dale, et alli, The same-sex attraction factsheet, disponibil la: SAEWYC, Elisabeth, et alli, Not Yet Equal: The Health of Lesbian, Gay, \& Bisexual Youth in BC, disponibil la: https://www.mcs.bc.ca/pdf/not_ yet_equal_web.pdf (accesat la 28.09.2019);

28. VAN WYK, Paul H., GEIST, Chrisann S., „Psychosocial development of heterosexual, bisexual, and homosexual behavior", în Archives of Sexual Behavior, Vol. 13, No. 6, December 1984, p. 505-544. 